UCRL-JC-129166

PREPRINT

\title{
Factors Affecting Performance of Engineered Barriers
}

\author{
J.A. Blink, R.W. Andrews, J.N. Bailey, T.W. Doering, J.H. Lee, \\ J.K. McCoy, D.G. McKenzie, D. Sevougian and V. Vallikat
}

This paper was prepared for submittal to the

American Nuclear Society

1998 International High-Level Radioactive Waste Management Conference

Las Vegas, $N V$

May 11-14, 1998

March 1998

This is a preprint of a paper intended for publication in a journal or proceedings. Since changes may be made before publication, this preprint is made available with the understanding that it will not be cited or reproduced without the permission of the author. 


\section{DISCLAIMER}

This document was prepared as an account of work sponsored by an agency of the United States Government Neither the United States Government nor the University of California nor any of their employees, makes any warranty, express or implied, or assumes any legal liability or responsibility for the accuracy, completeness, or usefulness of any information, apparatus, product, or process disclosed, or represents that its use would not infringe privately owned rights. Reference herein to any specific commercial product, process, or service by trade name, trademark, manufacturer, or otherwise, does not necessarily constitute or imply its endorsement, recommendation, or favoring by the United States Government or the University of California. The views and opinions of authors expressed herein do not necessarily state or reflect those of the United States Government or the University of California, and shall not be used for advertising or product endorsement purposes 


\title{
FACTORS AFFECTINO PERFORMANCE OF ENGINEERED BARRIERS
}

\author{
James Ai Blink, Lawrence Livermore National Laboratory, \\ Civillan Radloactive Waste Management System \\ Management and Operating Contractor (CRWMS M\&O); \\ Robert W. Andrews, Duke Engineering \& Services Inc., CRWMS, M\&O; \\ Jack N. Bailey, TRW, CRWMS M\&O; \\ Thomas W. Doering, Framatome Cogema Fuels, CRWMS, M\&O; \\ Joon H. Lee, Duke Engineering \& Services Inc., CRWMS, M\&O; \\ John Kevin McCoy, Framatome Cogema Fuels, CRWMS, M\&O; \\ Daniel G. McKenzle, Morrison-Knudsen Corporation, CRWMS, M\&O; \\ David Sevougian, Duke Engineering \& Services inc., CRWMS, M\&O; and \\ Vinod Vallikat, Duke Engineering \& Services Inc., CRWMS, M\&O
}

\section{INTRODUCTION}

For the Yucca Mountain Viability Assessment (VA), a reference design was tentatively selected' in September 1997, and a series of model abstractlons are being prepared for the performance assessment (PA) of that design. To determine the sensitivity of peak dose rate at the accessible environment to engineered components, several design options were subjected to the PA models available late in FY97.

\section{WORK DESCRIPTION}

The base case for the comparative study was the reference waste package (WP) design (2 $\mathrm{cm}$ of Alloy 625 nickel-base material inside $10 \mathrm{~cm}$ of Alloy 516 carbon steel) placed in a concrete lined drift. It was assumed that radionuclides are released from failed WPs by diffusion only. Outside the WPs, transport through the inverts is assumed to be diffusion limited for $90 \%$ of the failed WPs. In the remaining $10 \%$, transport is by advection. Improved corrosion models recommended by the Waste Package Degradation Expert Ellcltatlon (WPDEE) consultant group were used. For the thick corrosion allowance material (CAM), a pitting factor of 1.5 was used, with a standard deviation of 0.25 . For the thin corrosion resistant material (CRM), it was assumed that the pit growth rate declines with time and that pitting and crevice corrosion are less sensitive to temperature than assumed ${ }^{2}$ in TSPA-95.

Option 1 is a claddling credit case. Based on inventories, $1.15 \%$ of the 63,000 MTU of commercial spent nuclear fuel was assumed to be clad in stainless steel. It was conservatively assumed that the stainless steel would not be a substantlal barrler. About $0.1 \%$ of the zircalloy cladding is expected to arrive perforated, with opening sizes of order tens of microns. caused by creep rupture. Some additional rods were calculated to perforate in the repository due to creep rupture, based on temperature time histories within the WPs. For WPs which fail (and lose their inert gas) while the waste temperature is above $150^{\circ} \mathrm{C}$, oxidation and swelling of the $\mathrm{UO}_{2}$ is assumed to unzip perforated rods. Based on dry storage and spent nuclear fuel pool experience, perforated rods are assumed to have negligible releases if they do not unzip. Spent fuel in unzipped rods is assumed to have surface area increased by $100 x$. 
Option 2 is a backfill case. Credit was taken for reduced relative humidity under the backfill, due to the hlgher temperatures caused by the backfill's insulation of the Waste Package. To stay within the $350^{\circ} \mathrm{C}$ cladding temperature limit, the drifts were ventilated at $10 \mathrm{~m}^{3} / \mathrm{s}$ for 50 years. Based on a preliminary design analysis (which conservatively ignored latent heat removal), $80 \%$ of the heat released was assumed to be removed by the ventilation. A third case combined the cladding and backfill options.

Option 4 is a ceramic coating case. Since ceramics are thermodynamically stable in potential repository conditions and thus do not corrode significantly, the major uncertainty is whether flaws, handling stresses, thermal stresses, and rock falls can compromise the mechanical integrity of the coating and whether there will be slow movement of molsture through its pores. Backfill was assumed to be used to mitigate stresses from potential rock falls, and the ceramic was assumed to fail in a log-uniform distribution between 10,000 and 1,000,000 years. A sub-case had log-uniform failure between 1,000 and $1,000,000$ years.

The fifth option improves the CRM. Based on measured short term corrosion rates in extremely aggressive environments, a temperature-dependent Alloy C-22 corrosion rate $100 x$ below the Alloy 625 base case was assumed. A sub-case had a corrosion rate $10 x$ below the base case. Since this sensitivity study was completed, further corrosion data have been analyzed for Alloy C-22, and the WPDEE has provided site-specific corrosion rate estimates. As a result, the VA Reference Design is in the process of being changed to replace Alloy 625 with Alloy C-22.

\section{RESULTS}

The base case peak dose rate was $3.5 \mathrm{mrem} / \mathrm{yr}$. The uncertainty in input data and the transitional state of the PA models for the Viability Assessment results in low confidence in this value; however, it is suitable for the purpose of conducting this sensitivity analysis. The results for the base case and sensitivity cases are tabulated in Table 1.

Table 1.

\begin{tabular}{|c|c|c|}
\hline \multicolumn{3}{|c|}{ SENSITIVITY CASES ANALYZED } \\
\hline Caso & $\begin{array}{c}\text { Peak Dose } \\
\text { Rate } \\
\text { (mrem/yr) }\end{array}$ & $\begin{array}{c}\text { Reduction } \\
\text { from Base } \\
\text { Case }\end{array}$ \\
\hline Base Cas & 3.5 & - \\
\hline Cladding Credit & 0.08 & 40 \\
\hline Backfill at $50 \mathrm{yr}$, with Ventilation & 1.0 & 3.5 \\
\hline Backfill and Cladding Credli & 0.025 & 140 \\
\hline Ceramic Coating Failing between $10^{4}$ and $10^{6} \mathrm{yr}$ & 0.09 & 40 \\
\hline Ceramic Coating Failling between $10^{3}$ and $10^{6} \mathrm{yr}$ & 0.6 & 6 \\
\hline CRM with 100x Slower Corrosion Rate & 0.0 & $\infty$ \\
\hline CRM with 10x Slower Corrosion Rate & 0.03 & 100 \\
\hline
\end{tabular}


Cladding credit resulted in a peak dose rate of $0.08 \mathrm{mrem} / \mathrm{yr}$, about $40 x$ lower than the base case. Thls improvement is expected since less than $2 \%$ of the waste form is available for degradatlon and mobilization using these assumptions.

Backfill resuited in a peak dose rate of $1 \mathrm{mrem} / \mathrm{yr}$, about $3.5 x$ below the base case. The 60-year closure date was found to be achievable using the ventllation option, but construction costs increased due to the additional ventliation shafts required. Since this sensitivity study, It has been determined that the repository pre-closure period will be 100 years, rather than the 50-year period used in the study. This will reduce the required ventilation since the additional delay in backfll installation takes advantage of the reduction in heat rate due to natural decay.

The combination of backfill and cladding credlt resulted in a peak dose rate of $0.025 \mathrm{mrem} / \mathrm{yr}$, about $140 \mathrm{x}$ below the base case. The two options were essentially independent, with the resulting improvements being multiplicatlve.

A WP ceramlc coating resulted in a $0.09 \mathrm{mrem} / \mathrm{yr}$ peak dose rate, about $40 \mathrm{x}$ below the base case. When ceramic failure was extended to earller times, the peak dose rate was $0.6 \mathrm{mrem} / \mathrm{yr}$, about $6 \mathrm{x}$ below the base case. In principle, an intact ceramic coating would allow negligible releases; therefore, its PA is essentially an uncertalnty analysis. The assumptions used here are an indication of the potential performance available from a long-lived barrier, but are not based on mechanistlc or empirical ceramic fallure models. These models are being developed.

For the improved CRM with 100 times slower corrosion than the reference material, the calculation showed no releases. When the corrosion rate was only 10 times slower than the base case, the peak dose rate was $0.03 \mathrm{mrem} / \mathrm{yr}$, about 100 times below the base $\cos \theta$.

\section{CONCLUSIONS AND DISCUSSION}

Based on these sensitivity analyses, the improved corrosion resistant material (C-22) is an attractive option because it improves performance at least two orders of magnitude without requiring extensive design changes or increasing costs. Because of the sensitivity of performance to crevice corrosion, priority should be given to reducing its uncertainty, both experimentally and with process level modeling. The key factor in this uncertainty is the evolution of crevice chemistry, considering the chemistry of dripping water during the last part of the thermal pulse and thereafter.

Cladding has a slgnificant impact $(40 x)$ on performance. Historically, cladding integrity has been preserved by temperature limits, as a defense-in-depth factor. Because of its potentlal "base-case" performance impact, additional testing and literature evaluatlons of cladding may be appropriate.

Ceramics have the potential for even larger improvements in performance. To realize this potentlal, both the adherence of ceramic coatings to metal substrates under thermal and handling stresses and the permeablity of ceramlc coatings under long term exposure to radiation, moisture, and humidity must be established. Experimental efforts and natural analog literature searches have begun to obtain the necessary information. 
Backfill with pre-closure ventilation is a viable option to provide mechanical protection of the WP against rock fall without compromising cladding integrily. Increased ventilation adds significant construction cost which needs to be traded against the alternative of increased operating costs for delayed backfill emplacement.

\section{REFERENCES}

1. CRWMS Management and Operating Contractor, "Reference Design Description for a Geologlcal Repository," B00000000-01717-5707-00002, Rev. 1, November 25, 1997.

2. CRWMS Management and Operating Contractor, "Total System Performance Assessment - 1995", Document Identifier B00000000-01717-2200-00136, Rev. 00, August, 1995.

*This work was performed under the auspices of the U.S. Department of Energy by Lawrence Livermore National Laboratory under contract No. W-7405-Eng-48. 


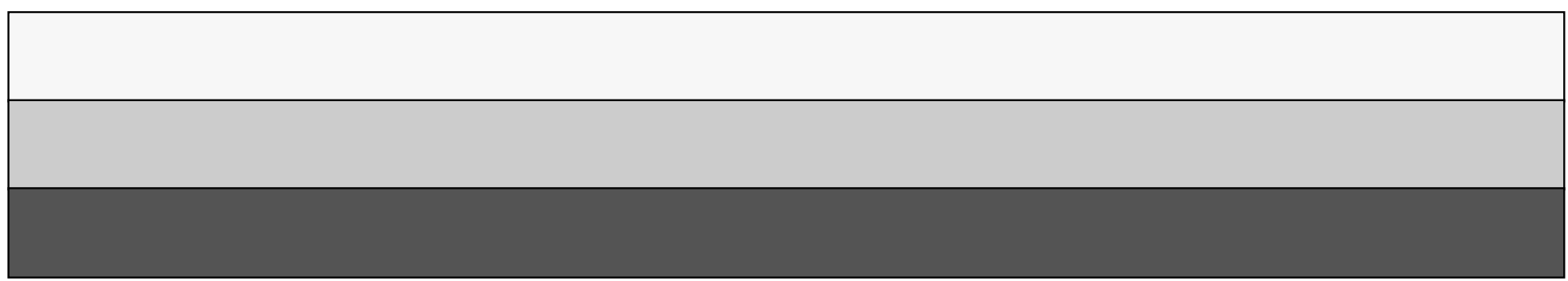

